ANALISIS USAHATANI KACANG PANJANG (Vigna Sinesis. L) DI KECAMATAN AMBULU KABUPATEN JEMBER

\title{
ANALYSIS OF LONG BEANS (Vigna Sinesis. L) FARMING IN AMBULU SUBDISTRICT OF JEMBER REGENCY
}

\author{
Avian Pratama Putra ${ }^{1}$, Syamsul Hadi ${ }^{2}$, Fefi Nurdiana Widjayanti ${ }^{2}$ \\ ${ }^{1}$ Mahasiswa Program Studi Agribisnis, Fakultas Pertanian, UM Jember \\ ${ }^{2}$ Dosen Program Studi Agribisnis, Fakultas Pertanian, UM Jember \\ email: avianpratama44@gmail.com
}

Diterima: 20 Oktober $2018 \quad$ Disetujui: 25 Februari 2019

\begin{abstract}
ABSTRAK
Kacang panjang adalah produk hortikultura yang memiliki prospek ekonomi yang baik, karena memiliki jumlah permintaan yang terus meningkat. Sementara di sisi lain prospek ekonomis tersebut belum didukung oleh tingkat pengelolaan usahatani yang lebih baik dan nilai jual produk yang memadai. Penelitian ini bertujuan (1) untuk menghitung keuntungan usahatani kacang panjang di Kecamatan Ambulu Kabupaten Jember, (2) untuk menghitung efisiensi penggunaan biaya produksi usahatani kacang panjang di Kecamatan Ambulu Kabupaten Jember, (3) untuk menganalisis faktor-faktor yang berpengaruh terhadap produksi usahatani kacang panjang di Kecamatan Ambulu Kabupaten Jember. Penelitian ini menggunakan metode deskriptif dan survey dengan pemilihan daerah dilakukan secara sengaja, dimana terpilih Kecamatan Ambulu, Kabupaten Jember sebagai lokasi sampel. Pengambilan sampel dilakukan secara proportioned random sampling, data diperoleh dari wawancara dengan petani dan instansi terkait. Metode analisis data yang digunakan adalah analisis keuntungan, RC-ratio, dan regresi non linier berganda. Penelitian ini menyimpulkan bahwa: (1) usahatani kacang panjang di Kecamatan Ambulu Kabupaten Jember menguntungkan. Rata-rata per hektar keuntungan yang diperoleh petani yaitu sebesar Rp 7.702.100 dalam sekali proses produksi (3-3,5 bulan). (2) hasil R/C pada usahatani kacang panjang per hektar diperoleh 1,416 sehingga usahatani kacang panjang sudah efisien dalam penggunaan biaya. (3) Faktor-faktor produksi yang menunjukan pengaruh signifikan pada usahatani kacang panjang di Kecamatan Ambulu Kabupaten Jember terdiri dari luas lahan, jumlah pupuk dan jumlah tenaga kerja. Sedangkan faktor produksi benih, dan pestisida mempunyai pengaruh yang tidak signifikan terhadap produksi usahatani kacang panjang di Kecamatan Ambulu Kabupaten Jember.
\end{abstract}

Kata Kunci: kacang panjang, keuntungan, efisiensi

\section{ABSTRACT}

Long beans are horticultural products that have good economic prospects, because they have a growing number of requests. While on the other hand the economic prospect has not been supported by a better level of farm management and adequate product selling value. This study aims to (1) calculate the benefits of long bean farming in Ambulu District, Jember Regency, (2) to calculate the efficiency of using long bean farming costs in Ambulu District, Jember Regency, (3) to analyze the factors that influence the production of peanut farming length in Ambulu District, Jember Regency. This study uses descriptive methods and surveys with deliberate regional selection, where Ambulu District, Jember District was chosen as the sample location. Sampling was carried out in proportioned random sampling, data obtained from interviews with farmers and related institutions. Data analysis methods used are profit analysis, RC-ratio, and multiple non-linear regression. This study concluded that: (1) long bean farming in Ambulu District, Jember Regency is beneficial. The average per hectare of profits obtained by farmers is IDR 7,702,100 in one production process (3-3.5 months). (2) the results of $R / C$ on long-bean farming per hectare obtained 1,416 so that long bean farming has been efficient in using costs. (3) Production factors that show significant influence on long bean farming in Ambulu District, Jember Regency consist of land area, amount of fertilizer and number of labor. While the factors of seed production, and pesticides have a non-significant effect on the production of long bean farming in Ambulu District, Jember Regency.

Keywords: long bean, profit, efficiency 


\section{PENDAHULUAN}

Peran sektor pertanian dalam pembangunan ekonomi sangat penting karena sebagian besar masyarakat indonesia pada tingkat taraf hidup miskin masih menggantungkan kelangsungan hidupnya pada sektor pertanian. Pertanian adalah suatu jenis kegiatan produksi yang berlandaskan proses pertumbuhan dari tumbuh-tumbuhan dan hewan. Pertanian dapat diartikan dalam arti sempit dan arti luas, pertanian dalam arti sempit dinamakan sebagai pertanian rakyat yaitu usaha pertanian keluarga yang memproduksi bahan makanan utama seperti beras dan palawija (rambutan, kacang-kacangan dan ubi-ubian) dan tanaman hortikultura (sayur-sayuran dan buahbuahan). Sedangkan pertanian dalam arti luas meliputi pertanian rakyat atau pertanian dalam arti sempit, perkebunan, kehutanan, peternakan dan perikanan (Soetriono, 2006)

Pembangunan hortikultura di Indonesia memiliki potensi yang cukup besar karena didukung dengan hukum, regulasi keanekaragaman hayati, ketersediaan lahan pertanian, agroklimat yang sesuai, dukungan teknologi, ketersediaan tenaga kerja, ketersediaan pasar, dukungan penetapan komoditas prioritas hortikultura, dukungan sistem perlindungan hortikultura. Sub sektor hortikultura di Indonesia mempunyai peranan penting dalam pembangunan perekonomian. Namun demikian masih banyak mengalami kendala, masalah dan tantangan tersebut di kelola dengan baik, dapat menjadikan Indonesia sebagai negara yang dapat di perhitungkan karena memiliki daya saing yang tinggi dan sumberdaya yang mampu memenuhi kebutuhan pembangunan hortikultura (Dirjen Hortikultura, 2015)

Menurut Cahyono (2005) bahwa kacang panjang (Vigna sinensis L.) merupakan salah satu jenis sayur kacang-kacangan. Kacang panjang memiliki nilai komersil tinggi dan mempunyai peran yang sangat besar dalam memenuhi kebutuhan pangan gizi masyarakat, terutama terhadap kebutuhan protein nabati. Peningkatan produksi kacang-kacangan masih harus ditingkatkan, karena komoditi ini banyak dikonsumsi oleh seluruh lapisan masyarakat. Faktor iklim dan tanah sangat berpengaruh terhadap pertumbuhan dan perkembangan tanaman kacang panjang. Tanaman ini dapat tumbuh dan berproduksi dengan baik menghendaki sifat fisik tanah yang gembur, kedalaman tanah cukup dalam dan tanah yang mudah mengikat air. Karena tanah yang gembur akan meningkatkan perkembangan perakaran, sehingga penyerapan hara berlangsung dengan baik yang berdampak bagi peningkatan pertumbuhan secara keseluruhan. Tanah yang gembur memiliki drainase yang baik. Jenis tanah yang cocok adalah regosol, andosol dan latosol yang merupakan tanah lempung ringan atau liat berpasir dengan tekstur tanah pasir sampai lempung berdebu. Jenis tanah ini pula memiliki daya ikat dan drainase yang baik.

Budidaya kacang panjang (Vigna Sinesis L.) memiliki prospek ekonomi yang baik. Pasar kacang panjang (Vigna Sinesis L.) yang telah jelas dan permintaan pasar yang selalu tinggi memudahkan para pembudidaya memasarkan hasil produksi kacang panjang. Kacang panjang (Vigna Sinesis L.) merupakan salah satu produk komersil dan dapat dikembangkan dengan teknik sederhana. Disamping itu, potensi pasar kacang panjang (Vigna Sinesis L.) masih sangat terbuka dan memiliki nilai ekonomis, sebab dapat dikonsumsi semua kalangan (Suriawiria, 2006).

Dari beberapa fenomena di atas, maka yang menjadi permasalahan adalah seberapa besar keuntungan usahatani kacang panjang? Faktorfaktor apa yang berpengaruh terhadap produksi usahatani kacang panjang? dan apakah petani sudah efisien dalam penggunaan biaya produksi pada kegiatan usahatani kacang panjang yang dilakukan? Untuk menjawab pertanyaan tersebut perlu dilakukan suatu penelitian yang mempelajari tentang usahatani kacang panjang yang dilakukan oleh petani selama ini dengan tujuan penelitian sebagai berikut: (1) untuk menghitung keuntungan usahatani kacang panjang di Kecamatan Ambulu Kabupaten Jember, (2) untuk menghitung efisiensi penggunaan biaya produksi usahatani kacang panjang di Kecamatan Ambulu Kabupaten Jember, (3) untuk menganalisis faktor-faktor yang berpengaruh terhadap produksi usahatani kacang panjang di Kecamatan Ambulu Kabupaten Jember.

\section{METODOLOGI PENELITIAN}

\section{Metode Penelitian}

Metode yang digunakan dalam penelitian ini adalah deskriptif dengan pendekatan survey. Nazir (2003) menyatakan bahwa metode deskriptif adalah suatu metode penelitian yang bertujuan untuk mengggambarkan peristiwa secara sistematis, faktual dan akurat mengenai faktafakta, sifat-sifat dan hubungan antar fenomena yang terjadi pada masa sekarang. Metode survey pada umumnya merupakan cara untuk pengumpulan data dari sejumlah unit atau individu dalam jangka waktu tertentu secara bersamaan. Metode survey dapat dilakukaan dengan cara melakukan wawancara secara langsung kepada petani responden (Nazir, 2003). 


\section{Penentuan Lokasi dan Waktu Penelitian}

Penelitian ini telah dilaksanakan di Kecamatan Ambulu Kabupaten Jember. Penentuan daerah penelitian dilakukan secara sengaja (purposive method). Didasarkan atas pertimbangan bahwa Kecamatan Ambulu memiliki luas panen dan produksi tertinggi di Kabupaten Jember, namun produktivitasnya paling rendah. Waktu penelitian berlangsung pada bulan Oktober 2018 .

\section{Metode Pengambilan Sampel}

Pengambilan sampel petani dilakukan dengan metode propotioned random sampling artinya pengambilan sampel dilakukan secara acak proporsional pada petani kacang panjang dari setiap desa yang ada di Kecamatan Ambulu Kabupaten Jember. Agar memperoleh sampel yang representatif dari populasi, maka setiap subyek dalam populasi diupayakan memiliki peluang yang sama untuk menjadi sampel. Adapun rumusan yang digunakan untuk mengukur sampel digunakan rumus Slovin dalam Umar. H (2004) sebagai berikut:

Keterangan:

$$
n=\frac{N}{1+N e^{2}}
$$

Tabel 1 Distribusi Populasi dan Sampel Petani Kacang Panjang di Kecamatan Ambulu

\begin{tabular}{clcc}
\hline No & \multicolumn{1}{c}{ Desa } & $\begin{array}{c}\text { Populasi } \\
\text { (Petani) }\end{array}$ & $\begin{array}{c}\text { Sampel } \\
\text { (Petani) }\end{array}$ \\
\hline 1 & Sumberejo & 72 & 27 \\
2 & Andongsari & 41 & 21 \\
3 & Sabrang & 53 & 24 \\
\hline
\end{tabular}

Sumber: Data Sekunder Diolah (2018)

\section{Metode Pengumpulan Data}

Sumber data yang digunakan dalam penelitian ini adalah data primer dan data sekunder. Data primer dikumpulkan secara langsung dari petani yang melakukan usahatani kacang panjang dengan metode wawancara menggunakan kuisioner yang telah dipersiapkan. Data sekunder merupakan data yang diperoleh dari dinas atau instansi yang berhubungan dengan penelitian ini. Data-data tersebut dikumpulkan dengan cara mendatangi dinas atau instansi yang terkait dan meminta data yang berhubungan dengan penelitian.

\section{Metode Analisis Data}

Dalam penelitian ini, metode analisis data yang akan digunakan untuk menguji hipotesis dalam penelitian ini adalah:

1. Untuk mengukur besarnya tingkat produktivitas dilakukan dengan formulasi sebagai berikut:

$$
\mathrm{Y}=\frac{\mathrm{Q}}{\mathrm{A}}
$$

Keterangan:

$\mathrm{Y}=$ Produktivitas lahan

$\mathrm{Q}=$ Produksi $(\mathrm{kg})$

$\mathrm{A}=$ Luas lahan (ha)

2. Untuk menguji hipotesis pertama tentang keuntungan dilakukan dengan menggunakan pendekatan teori keuntungan dengan formulasi sebagai berikut (Sukirno, 2001):
$T R=P \cdot Q$

$T C=T F C+T V C$

Keterangan :

$\pi \quad=$ keuntungan $(\mathrm{Rp})$

$T R \quad=$ total penerimaaan $(\mathrm{Rp})$

$T C=$ total biaya $(\mathrm{Rp})$

$\mathrm{P} \quad=$ harga produksi per $\mathrm{kg}(\mathrm{Rp})$

$Q \quad=$ produksi $(\mathrm{kg})$

TFC = total biaya tetap (Rp)

TVC = total biaya variabel $(\mathrm{Rp})$

Kriteria pengambilan keputusan:

a. $\quad$ TR $\leq$ TC menunjukkan bahwa usahatani kacang panjang tidak menguntungkan

b. $\quad \mathrm{TR} \geq \mathrm{TC}$ menunjukkan bahwa usahatani kacang panjang menguntungkan

3. Pengujian hipotesis yang kedua tentang efisiensi biaya produksi digunakan analisis $\mathrm{RC}$-ratio dengan formulasi sebagai berikut (Soekartawi 1995):

$R C-$ ratio $=\frac{T R}{T C}$

Dimana:

$\mathrm{TR}=$ total penerimaan

$\mathrm{TC}=$ total biaya

Kriteria pengambilan keputusan :

a. $\mathrm{R} / \mathrm{C}>1$, maka biaya produksi yang digunakan efisien

b. $\mathrm{R} / \mathrm{C} \leq 1$, maka biaya produksi yang digunakan tidak efisien 
4. Untuk menguji hipotesis yang ketiga, yaitu mengetahui faktor-faktor yang berpengaruh terhadap produksi usahatani kacang panjang digunakan pendekatan analisis regresi berganda, dengan asumsi bahwa bentuk hubungan antara variabel $(\mathrm{X})$ dengan variabel (Y) merupakan fungsi produksi CobbDouglas. Hubungan antara variabel $\mathrm{X}$ dan $\mathrm{Y}$ tersebut, secara matematik dirumuskan sebagai berikut (Soekartawi, 1995):

$$
Y_{i}=\beta_{0} X_{1_{i}}^{\beta_{1}} X_{2_{i}}^{\beta_{2}} \ldots X_{k}^{\beta_{k}} e^{\mu_{i}}
$$

Diduga faktor-faktor yang berpengaruh terhadap produksi adalah luas lahan, benih, pupuk, pestisida, jumlah tenaga kerja. Secara matematis, persamaan taksiran fungsi produksi dengan model regresi adalah:

di mana:

$$
\hat{Y}=\beta_{0} X_{1}^{\beta_{1}} X_{2}^{\beta_{2}} X_{3}^{\beta_{3}} X_{4}^{\beta_{4}} X_{5}^{\beta_{5}}
$$

$\hat{Y}=$ estimator dari $\mathrm{Y}=$ produksi

usahatani kacang panjang $(\mathrm{kg})$

$\mathrm{X}_{1} \quad$ = luas lahan (ha)

$\mathrm{X}_{2} \quad=$ jumlah benih $(\mathrm{kg})$

$\mathrm{X}_{3} \quad=$ jumlah pupuk $(\mathrm{kg})$

$\mathrm{X}_{4} \quad=$ jumlah pestisida $(\mathrm{kg})$

$\mathrm{X}_{5}=$ jumlah tenaga kerja (HKP)

$\beta_{0} \quad=$ konstanta

$\beta_{1-5} \quad=$ koefisien regresi variabel bebas

Untuk memudahkan pendugaan maka persamaan di atas diubah menjadi bentuk linear berganda dengan cara melogaritmakan persamaan tersebut, sehingga persamaannya menjadi:

\section{keterangan:}

$\ln Y=\ln a+\beta_{1} \ln X_{1}+\beta_{2} \ln X_{2}+\beta_{3} \ln X_{3}$

$$
+\beta_{4} \ln X_{4}+\beta_{5} \ln X_{5}
$$

$\mathrm{Y}=$ Produksi usahatani kacang panjang $(\mathrm{kg})$

$\alpha \quad=$ Konstanta

$\beta_{1-6}=$ Koefisien regresi

$\mathrm{X}_{1} \quad=$ luas lahan (ha)

$\mathrm{X}_{2} \quad=$ jumlah benih $(\mathrm{kg})$

$\mathrm{X}_{3} \quad=$ jumlah pupuk $(\mathrm{kg})$

$\mathrm{X}_{4} \quad=$ jumlah pestisida $(\mathrm{kg})$

$\mathrm{X}_{5} \quad=$ jumlah tenaga kerja (HKP)

Setelah koefisien regresi diperoleh, maka untuk mengetahui keberartian koefisien secara satuan (bersama-sama).

$\mathrm{H}_{0} \quad$ : Semua koefisien regresi parsial dari faktor-faktor tertentu secara bersama-sama tidak berpengaruh terhadap produksi, atau $\beta_{1}=\beta_{2}=\beta_{3}=\ldots=$ $\beta_{5}=0$

$\mathrm{H}_{\mathrm{a}} \quad$ : Minimal atau paling sedikit koefisien regresi parsial dari faktor-faktor tertentu secara bersama-sama berpengaruh terhadap produksi, atau $\beta_{1} \neq$ $\beta_{2} \neq \beta_{3} \neq \ldots \neq \beta_{5} \neq 0$

Analisa yang telah dihitung kemudian dilanjutkan dengan uji $\mathrm{F}$ yang merupakan uji kebenaran terhadap model persamaan diatas, kemudian menghitung $\mathrm{R}^{2}$ yang formulasinya sebagai berikut:

$$
\begin{gathered}
F \text { hitung }=\frac{\text { Kuadrat Tengah Regresi }}{\text { Kuadrat Tengah Sisi }} \begin{array}{c}
\text { atau } R^{2} \\
=\frac{J K R}{J K T}
\end{array}
\end{gathered}
$$

Kriteria pengambilan keputusan:
a. $\quad \mathrm{F}_{\text {hitung }} \leq(0,05 ; \mathrm{n}-\mathrm{k}-1)$, maka $\mathrm{H}_{0}$ diterima

b. $\quad F_{\text {hitung }}>(0,05 ; \mathrm{n}-\mathrm{k}-1)$, maka $\mathrm{H}_{0}$ ditolak

Dilanjutkan dengan uji-t untuk mengetahui pengaruh masing-masing variabel independen terhadap variabel dependen dengan rumus sebagai berikut:

$$
\begin{array}{r}
t_{\text {hitung }}=\frac{b i}{S_{b i}} \text { dengan } S_{b i} \\
=\sqrt{\frac{\text { Jumlah Kuadrat Sisa }}{X_{i^{2}}}}
\end{array}
$$

Keterangan:

bi $\quad=$ Koefisien regresi

$\mathrm{S}_{\mathrm{bi}} \quad=$ Standar deviasi bi

Untuk mengetahui keberartian koefisien regresi parsial secara individu yaitu:

$\mathrm{H}_{0} \quad$ : Koefisien regresi parsial dari faktorfaktor tertentu tidak berpengaruh terhadap produksi, atau $\beta_{\mathrm{j}}=0$

$\mathrm{H}_{\mathrm{a}} \quad$ : Minimal atau paling sedikit koefisien regresi parsial dari faktor-faktor tertentu berpengaruh terhadap produksi, atau $\beta_{\mathrm{j}} \neq 0$

Kriteria pengambilan keputusan:

a. $\quad t_{\text {hitung }} \leq(0,05 ; n-k-1)$, maka $\mathrm{H}_{0}$ diterima

b. $\quad t_{\text {hitung }}>(0,05 ; n-k-1)$, maka $\mathrm{H}_{0}$ ditolak.

\section{HASIL DAN PEMBAHASAN}

\section{Tingkat Produktivitas Usahatani Kacang Panjang di Kecamatan Ambulu Kabupaten Jember}

Dalam penelitian usahatani kacang panjang yang dilakukan di Kecamatan Ambulu diketahui rata-rata luas lahan, produksi, dan produktivitas sebagai berikut. 
Tabel 2 Rata-rata Luas lahan, produksi, dan Produktivitas Kacang Panjang di Kecamatan Ambulu.

\begin{tabular}{ccc}
\hline $\begin{array}{c}\text { Luas Lahan } \\
(\mathbf{h a})\end{array}$ & $\begin{array}{c}\text { Produksi } \\
(\mathbf{k g})\end{array}$ & $\begin{array}{c}\text { Produktivitas } \\
(\mathbf{k g} / \mathbf{h a})\end{array}$ \\
\hline 0,31 & 2.864 & $9.188,95$ \\
\hline Sumber : Data Primer Diolah 2018 & &
\end{tabular}

Hasil penelitian mengungkapkan bahwa produktivitas usahatani kacang panjang di Kecamatan Ambulu mencapai 91,88 kw/ha sedangkan rata-rata produktivitas menurut Badan Pusat Statistik Jember tahun 2016 untuk Kecamatan Ambulu mencapai 38,74 kw/ha, artinya produktivitas kacang panjang di Kecamatan Ambulu mengalami peningkatan.

\section{Analisis Keuntungan Usahatani Kacang Panjang di Kecamatan Ambulu Kabupaten Jember}

Komponen biaya yang dikeluarkan oleh petani kacang panjang terdiri dari biaya tetap dan biaya variable. Biaya tetap adalah biaya yang dikeluarkan terdiri dari biaya penyusutan alat, biaya ajir, dan biaya sewa lahan. Sedangkan biaya variable adalah biaya yang terdiri dari benih, pupuk, pestisida, dan biaya tenaga kerja. Secara terperinci rata-rata biaya usahatani kacang panjang disajikan pada Tabel 3 di bawah. Menurut Soekartawi (1995) bahwa biaya diklarifikasikan menjadi dua, yaitu biaya tetap (fixed cost) dan biaya variabel (variable cost). Biaya tetap adalah biaya yang relatif tetap jumlahnya dan terus dikeluarkan, walaupun produksi yang diperoleh banyak ataupun sedikit, misalnya sewa tanah, alat pertanian, dan lain sebagainya. Biaya variabel adalah biaya yang besar kecilnya di pengaruhi oleh produksi yang diperoleh, contohnya adalah pupuk, benih, pestisida, dan upah tenaga kerja. Jumlah biaya tetap seluruhnya dan biaya variabel seluruhnya merupakan biaya total produksi, sehingga dapat diformulasikan sebagai berikut:
$T C=T F C+T V C$

di mana:

$\mathrm{TC}=$ Biaya Total Produksi

TFC $=$ Biaya Tetap Total

$\mathrm{TVC}=$ Biaya Variabel Total

Berdasarkan pada Tabel 3 menunjukkan bahwa penggunaan total biaya rata-rata usahatani kacang panjang per hektar sebesar Rp 18.514.668 selama satu kali proses produksi, biaya tetap mencapai 51\% atau sebesar Rp 9.459.019/ha dan biaya variable $49 \%$ atau sebesar Rp 9.055.649/ha, berdasarkan perhitungan dari biaya tetap terdapat tiga variabel yaitu sewa lahan, penyusutan alat, dan biaya ajir, dari ketiga biaya tersebut biaya pembuatan ajir memiliki nilai biaya yang paling besar yaitu Rp 4.813.439/ha atau 25,9\% dari total biaya keseluruhan, selanjutnya yang termasuk biaya variable diantaranya benih, pupuk, pestisida, dan tenaga kerja, dengan total sebesar Rp 9.055.649/ha atau $49 \%$ dari total biaya keseluruhan.

Jika dibandingkan dengan penelitian yang dilakukan oleh Saepul (2013) bahwa total biaya yang di keluarkan petani kacang panjang di Kecamatan Nagrak Kabupaten Sukabumi sebesar Rp 23.731.018 selama satu kali proses produksi, jauh lebih besar dibandingkan dengan total biaya produksi kacang panjang yang dilakukan petani di Kecamatan Ambulu Kabupaten Jember yaitu hanya sebesar Rp 18.586.856, hal ini terjadi karena adanya perbedaan harga saprodi di daerah penelitian.

Tabel 3 Hasil Analisis Rata-rata Biaya Usahatani Kacang Panjang Perhektar di Kecamatan Ambulu Kabupaten

\begin{tabular}{|c|c|c|c|c|c|}
\hline No & Komponen Biaya & Jumlah & Harga Satuan (Rp) & Nilai (Rp) & $\%$ \\
\hline \multirow[t]{5}{*}{1} & Tetap & & & & \\
\hline & Sewa Lahan & 1 & 4.538 .888 & 4.538 .888 & $24,5 \%$ \\
\hline & Penyusutan Alat & & & 106.692 & $0,6 \%$ \\
\hline & Ajir (batang) & 16045 & 300 & 4.813 .439 & $26,0 \%$ \\
\hline & Sub Total & & & 9.459 .019 & $51,1 \%$ \\
\hline \multirow[t]{11}{*}{2} & Variabel & & & & \\
\hline & Sarana Produksi & & & & \\
\hline & Benih (kg) & 8,6 & 34.905 & 301.046 & $1,6 \%$ \\
\hline & Urea $(\mathrm{kg})$ & 28 & 1.921 & 54.128 & $0,3 \%$ \\
\hline & $\mathrm{Za}(\mathrm{Kg})$ & 54 & 1.322 & 71.251 & $0,4 \%$ \\
\hline & NPK $(\mathrm{Kg})$ & 144 & 2.432 & 349.230 & $1,9 \%$ \\
\hline & Decis (botol) & 6 & 33.856 & 217.512 & $1,2 \%$ \\
\hline & Score (botol) & 1 & 150.000 & 80.369 & $0,4 \%$ \\
\hline & Tenaga kerja (HKP) & 319 & 25.000 & 7.982 .113 & $43,1 \%$ \\
\hline & Sub Total & & & 9.055 .649 & $48,9 \%$ \\
\hline & Total Biaya & & & 18.514.668 & \\
\hline
\end{tabular}

Sumber: Analisis Data Primer (2018) 
Keuntungan adalah selisih antara penerimaan dan biaya, penerimaan adalah total hasil yang diterima petani dalam jumlah hasil produksi yang dihasilkan. Penerimaan diperoleh dari perkalian jumlah produksi dengan harga produk ditingkat pasar. Makin besar jumlah produksi yang dihasilkan maka semakin besar pula penerimaan yang akan didapatkan oleh petani, akan tetapi jika jumlah produksi yang dihasilkan tinggi, namun jika harga produk menurun maka penerimaan yang akan diterima oleh petani akan kecil. Penerimaan yang diperoleh oleh petani kacang panjang berasal dari perkalian antara produksi selama satu periode produksi (3-3.5 bulan) dengan harga jual produk. Harga produk kacang panjang sangat bervariasi tergantung pada kualitas, produksi yang melimpah dan kondisi pasar, sehingga penerimaan petani kacang panjang sangat berbeda. Kacang panjang memerlukan waktu 3-3.5 bulan untuk satu kali proses produksi, sehingga dalam setahun ada 3 kali proses produksi.

Tujuan akhir yang diharapkan dari suatu kegiatan usahatani kacang panjang adalah memperoleh keuntungan setinggi mungkin. Keuntungan tidak hanya ditentukan oleh tingginya produksi, akan tetapi juga ditentukan oleh harga dan besarnya biaya yang dikeluarkan.

Menurut Sukirno (2001), keuntungan adalah perbedaan nilai uang dari hasil penjualan yang diperoleh dengan seluruh biaya yang dikeluarkan. Secara matematis, keuntungan dapat diformulasikan sebagai berikut:

$$
\begin{aligned}
\pi & =\mathrm{TR}-\mathrm{TC} \\
& =\mathrm{PQ}-\mathrm{C}
\end{aligned}
$$

Keterangan:

$\pi \quad=$ keuntungan

$\mathrm{TR}=$ Total Revenue (penerimaan total)

$\mathrm{TC}=$ Total Cost (biaya total)

$\mathrm{P} \quad=$ Price (harga produksi)

$\mathrm{Q}=$ Quantity (jumlah produksi)

$\mathrm{C}=\operatorname{cost}$ (biaya)

Untuk mengetahui rata-rata keuntungan yang diperoleh petani kacang panjang di Kecamatan Ambulu Kabupaten Jember dapat dilihat pada Tabel 6.3 sebagai berikut:

Tabel 4 Hasil Analisis Rata-rata Keuntungan Usahatani Kacang Panjang Perhektar di Kecamatan Ambulu Kabupaten Jember

\begin{tabular}{lcr}
\hline \multicolumn{1}{c}{ Uraian } & Satuan & \multicolumn{1}{c}{ Rata-rata } \\
\hline Produksi & $\mathrm{Kg}$ & 9.243 \\
Harga & $\mathrm{Rp} / \mathrm{kg}$ & 2.836 \\
Penerimaan & $\mathrm{Rp}$ & 26.216 .767 \\
Biaya & $\mathrm{Rp}$ & 18.514 .668 \\
\hline Keuntungan & $\mathbf{R p}$ & $\mathbf{7 . 7 0 2 . 1 0 0}$ \\
\hline Sumber: Analisis Data Primer $(2018)$ &
\end{tabular}

Pada Tabel 4 menunjukkan bahwa usahatani kacang panjang di Kecamatan Ambulu Kabupaten Jember menguntungkan karena penerimaan lebih besar dibanding biaya. Rata-rata produksi per hektar $9.243 \mathrm{~kg}$ dan rata-rata harga kacang panjang sebesar Rp 2.836 di tingkat petani sehingga penerimaan yang diterima oleh petani kacang panjang sebesar Rp 26.216.767 sedangkan biaya yang dikeluarkan selama satu kali proses produksi senilai Rp 18.514.668, sehingga keuntungan yang diperoleh sebesar Rp 7.702.100.

Penelitian ini sejalan dengan penelitian yang dilakukan oleh Reffi (2014) menyatakan bahwa pendapatan rata-rata yang diterima petani adalah Rp 31.079.781 per hektar per musim tanam dengan keuntungan sebesar Rp 13.729.042 per hektar per musim tanam. Dengan demikian usahatani ini sudah dapat dikatakan berhasil atau layak untuk dijalankan, karena pendapatan dan keuntungan yang diperoleh petani dapat membayar biaya-biaya yang dikeluarkan usahatani tersebut.

\section{Analisis Efisiensi Usahatani Kacang Panjang di} Kecamatan Ambulu Kabupaten Jember

Tingkat keberhasilan usahatani kacang panjang dapat dilihat dari efisiensi penggunaan biaya, apabila petani memperoleh keuntungan yang tinggi dari hasil usahatani kacang panjang, dan keuntungan tersebut melebihi biaya produksi yang dikeluarkan oleh petani selama proses produksi maka dapat dikatakan usahatani kacang panjang yang dilakukan menguntungkan dan biaya yang dikeluarkan efisien.

Menurut Soekartawi (1995), efisiensi usahatani dipengaruhi oleh penerimaan dan total biaya yang dikeluarkan selama proses produksi. Suatu usahatani adalah efisien, jika penerimaan yang diterima lebih tinggi dibandingkan dengan biaya. RC-ratio adalah singkatan dari Return Cost Rasio, yaitu perbandingan antara penerimaan dan biaya produksi. Secara matematik, hal ini dapat dituliskan sebagai berikut:

$a=R / C$

di mana:

$\mathrm{a}=$ Efisiensi Biaya

$\mathrm{R}=\mathrm{TR}=$ Penerimaan $=\mathrm{P} \times \mathrm{Q}$

$\mathrm{C}=$ Biaya $=\mathrm{FC}+\mathrm{VC}$

Analisis R/C merupakan salah satu cara untuk mengetahui tingkat efisiensi biaya suatu usahatani. Efisiensi adalah tingkat perbandingan antara penerimaan dengan biaya total yang dikeluarkan selama proses produksi usahatani kacang panjang. usahatani dikatakan efisien apabila nilai perbandingan yang diperoleh antara penerimaan dengan biaya lebih dari satu (1). (R/C $>1$ ), dikatakan tidak efisien apabila kurang dari satu $(1)(\mathrm{R} / \mathrm{C}<1)$, dan jika nilai $(\mathrm{R} / \mathrm{C}=1)$ maka penggunaan biaya produksi belum efisien. Nilai 
efisiensi biaya kacang panjang di Kecamatan Ambulu Kabupaten Jember disajikan pada Tabel 6.4:

Tabel 5 Hasil Analisis Rata-rata Efisiensi Biaya Usahatani Kacang Panjang di Kecamatan Ambulu Kabupaten Jember

\begin{tabular}{lcr}
\hline \multicolumn{1}{c}{ Uraian } & Satuan & Analisis Efisiensi \\
\hline Penerimaan & $\mathrm{Rp}$ & 26.216 .767 \\
Biaya & $\mathrm{Rp}$ & 18.514 .668 \\
R/C & & 1,416 \\
\hline Sumber: Analisis Data Primer (2018) &
\end{tabular}

Tabel 5 menunjukkan bahwa nilai R/C yang dihasilkan sebesar 1,416 artinya setiap pengeluaran biaya sebesar Rp 1 akan menghasilkan penerimaan sebesar Rp 1,416 atau pengeluaran biaya sebesar Rp 1.000 akan menghasilakan penerimaan sebesar $\mathrm{Rp}$ 1.416. Besarnya nilai $\mathrm{R} / \mathrm{C}$ yang diperoleh petani lebih dari satu $(\mathrm{R} / \mathrm{C}>1)$, maka dapat dikatakan bahwa usahatani kacang panjang di Kecamatan Ambulu Kabupaten Jember sudah efisien.

Hasil ini di dukung oleh peneliti sebelumnya menurut Saepul (2013) bahwa

Tabel 6 Hasil Analisis Regresi Faktor-faktor Yang Mempengaruhi Produksi Kacang Panjang di Kecamatan Ambulu Kabupaten Jember

\begin{tabular}{|c|c|c|c|c|c|}
\hline Variabel & Parameter & $\begin{array}{c}\text { Koefisien } \\
\text { Regresi }\end{array}$ & $\begin{array}{c}\text { Std. } \\
\text { Error }\end{array}$ & $\mathbf{t}$ & Signifikansi \\
\hline Konstanta & $\beta_{0}$ & 7,254 & 0,421 & $17,213 * * *$ & 0,000 \\
\hline Luas Lahan $\left(\mathrm{X}_{1}\right)$ & $\beta_{1}$ & 0,591 & 0,086 & $6,904 * * *$ & 0,000 \\
\hline Jumlah Benih $\left(\mathrm{X}_{2}\right)$ & $\beta_{2}$ & 0,105 & 0,065 & $1,612^{\mathrm{ns}}$ & 0,112 \\
\hline Jumlah Pupuk $\left(\mathrm{X}_{3}\right)$ & $\beta_{3}$ & 0,141 & 0,055 & $2,548 * *$ & 0,013 \\
\hline Jumlah Pestisida $\left(\mathrm{X}_{4}\right)$ & $\beta_{4}$ & $-0,001$ & 0,019 & $-0,075^{\mathrm{ns}}$ & 0,940 \\
\hline Jumlah Tenaga Kerja $\left(\mathrm{X}_{5}\right)$ & $\beta_{5}$ & 0,154 & 0,046 & $3,324 * * *$ & 0,001 \\
\hline Multiple R & $\mathrm{R}$ & 0,984 & & & \\
\hline R Square & $\mathrm{R}^{2}$ & 0,968 & & & \\
\hline Adjusted R Square & $\overline{\mathrm{R}}^{2}$ & 0,966 & & & \\
\hline Standard Error & se & 0,079 & & & \\
\hline F-ratio & & $404,908 * * *$ & & & \\
\hline $\mathrm{n}$ & & 72 & & & \\
\hline
\end{tabular}

Keterangan: $(* * *)=$ signifikan pada $\alpha 99 \%,\left({ }^{* *}\right)=$ signifikan pada $\alpha 95 \%$, ns $=$ non signifikan

Sumber: Analisis Data Primer (2018)

Berdasarkan hasil analisis regresi fungsi produksi maka, persamaan fungsi produksi linier usahatani kacang panjang dapat dirumuskan:

$\ln \mathrm{Y}=7,254+0,591 \ln \mathrm{X}_{1}+0,105 \ln \mathrm{X}_{2}+0,141$ $\ln \mathrm{X}_{3}-0,001 \ln \mathrm{X}_{4}+0,154 \ln \mathrm{X}_{5}$

Persamaan linier tersebut dimasukkan sehingga fungsi produksi cobb-douglas usahatani kacang panjang sebagai berikut:

$Y=1414,046 X_{1}^{0,591} X_{2}^{0,105} X_{3}^{0,141} X_{4}^{-0,001} X_{5}^{0,154}$

Faktor-faktor yang diduga berpengaruh terhadap produksi kacang panjang disajikan pada kegiatan usahatani kacang panjang yang yang dilakukan petani di Kecamatan Nagrak efisien dan menguntungkan untuk diusahakan dikarenakan nilai $\mathrm{R} / \mathrm{C}$ rasio atas biaya tunai yang diperoleh sebesar 2,22 dan $\mathrm{R} / \mathrm{C}$ rasio atas biaya total sebesar 1,76 yang berarti penerimaan yang diperoleh petani kacang panjang dapat menutupi biaya usahatani yang dikeluarkan.

Faktor-faktor yang Mempengaruhi Produksi Kacang Panjang di Kecamatan Ambulu Kabupaten Jember

Hasil akhir dari suatu proses produksi dipengaruhi oleh besar atau kecilnya input dan teknologi yang digunakan. Hubungan antara jumlah penggunaan input dan produksi yang dihasilkan, pada tingkat teknologi tertentu disebut fungsi produksi, input sering pula disebut dengan korbanan atau faktor produksi, karena faktor produksi tersebut di korbankan untuk menghasilkan produksi. Untuk menghasilkan suatu produk, maka diperlukan pengetahuan tentang hubungan antara faktor produksi dan produksi. adalah output atau produksi. Jumlah produksi akan 
mengidentifikasikan variasi variabel dependen (produksi) secara baik sekitar 96,6\%. Hanya 3,4\% yang dijelaskan oleh faktor lain yang tidak masuk ke dalam model.

Apabila dilihat dari nilai koefisien regresi parsial yang menggunakan full-model, maka faktor produksi luas lahan, jumlah pupuk, dan tenaga kerja berpengaruh secara signifikan terhadap produksi usahatani kacang panjang. Sementara pengaruh dari variabel benih, dan pestisida berpengaruh tidak signifikan.

\section{a. Luas Lahan $\left(\mathbf{X}_{1}\right)$}

Luas lahan secara statistik berpengaruh sangat signifikan pada taraf uji $1 \%$ terhadap produksi usahatani kacang panjang. Hasil analisis menunjukkan bahwa nilai koefisien regresi dari faktor luas lahan adalah senilai 0,591 yang artinya dari setiap penambahan luas lahan rata-rata sebesar $1 \%$ maka akan cenderung menambah produksi sebanyak $0,591 \%$. Koefisien regresi bernilai positif sebesar 0,591 mengindikasikan bahwa produksi masih dapat ditingkatkan melalui peningkatan luas lahan, dengan asumsi faktor lainnya konstan. Penelitian ini sejalan dengan penelitian Nizar (2002) dalam hasil penelitiannya menyatakan bahwa luas lahan berpengaruh positif dan nyata terhadap hasil produksi dan dengan asumsi faktor lain tetap.

\section{b. Benih $\left(\mathbf{X}_{2}\right)$}

Pengaruh faktor penggunaan benih berpengaruh positif, akan tetapi secara statistik tidak signifikan pada taraf uji 10\%. Artinya, semakin banyak benih yang digunakan berpengaruh tidak nyata terhadap produksi usahatani kacang panjang. Peningkatan penggunaan benih sebesar $1 \%$ akan mampu meningkatkan produksi kacang panjang sebesar $0,105 \%$. Daerah ini merupakan daerah rasional artinya pada daerah ini masih bisa dimungkinkan untuk meningkatkan penggunaan benih untuk mencapai produksi yang maksimum.

Menurut Saepul (2013) Berdasarkan informasi yang diperoleh dari lapangan jarak tanam yang digunakan petani di daerah penelitian yaitu rata-rata 20x50 centimeter dengan jumah benih yang ditanam sebanyak dua biji per lubang tanam. Peningkatan penggunaan benih dapat ditingkatkan dengan cara memperkecil jarak tanam menjadi 20x40 centimeter. Penggunaan rata-rata benih kacang panjang di Kecamatan Nagrak yaitu sebesar 8790 gram/ha, masih dibawah potensi maksimal penggunaan benih kacang panjang sebanyak 20.000 gram per hektar.

\section{c. Pupuk $\left(\mathbf{X}_{3}\right)$}

Faktor pupuk secara statistik berpengaruh signifikan pada taraf uji 5\% terhadap produksi usahatani kacang panjang, hasil regresi menunjukkan bahwa nilai koefisien regresi dari pupuk adalah senilai 0,141 yang artinya dari setiap penambahan pupuk rata-rata sebesar $1 \%$ maka akan cenderung menambah produksi sebanyak $0,141 \%$, dengan asumsi variabel produksi lainnya dianggap tetap.

\section{d. Pestisida $\left(\mathbf{X}_{4}\right)$}

Faktor pestisida berpengaruh negatif dan secara statistik berpengaruh tidak signifikan terhadap produksi usahatani kacang panjang pada taraf uji 10\%, hasil regresi menunjukkan bahwa nilai koefisien regresi dari pestisida adalah senilai 0,001 yang artinya dari setiap penambahan pestisida rata-rata sebesar $1 \%$ maka akan cenderung menurunkan produksi sebanyak $0,001 \%$, dengan asumsi variabel produksi lainnya dianggap tetap. Adanya penggunaan pestisida yang sama secara terus menerus dapat menyebabkan hama pada tanaman kacang panjang menjadi resisten. Dengan kata lain penggunaan pestisida terlalu banyak, penggunaan pestisida oleh petani kacang panjang di Kecamatan Ambulu Kabupaten Jember rata-rata sebanyak $728 \mathrm{ml} / \mathrm{ha}$. Hasil ini bertolak belakang dengan penelitian sebelumnya menurut Saepul (2013) bahwa hasil penelitian menyatakan bahwa jumlah pestisida berpengaruh positif terhadap hasil produksi dan nyata dengan asumsi faktor lain tetap.

\section{e. Tenaga Kerja $\left(\mathbf{X}_{5}\right)$}

Faktor tenaga kerja secara statistik berpengaruh signifikan pada taraf uji $1 \%$ terhadap produksi usahatani kacang panjang, hasil regresi menunjukkan bahwa nilai koefisien regresi dari tenaga kerja adalah senilai 0,154 yang artinya dari setiap penambahan jumlah tenaga kerja sebesar $1 \%$ maka akan menambah produksi sebanyak $0,154 \%$, dengan asumsi variabel produksi lainnya dianggap tetap. Hasil ini didukung oleh peneliti sebelumnya menurut Nizar (2002) dalam hasil penelitiannya menyatakan bahwa tenaga kerja berpengaruh positif dan nyata

\section{KESIMPULAN DAN SARAN \\ 1. Kesimpulan}

Berdasarkan hasil penelitian, analisis dan pembahasan maka dapat diambil kesimpulannya sebagai berikut:

1. Produktivitas usahatani kacang panjang di Kecamatan Ambulu dalam penelitian yaitu rata-rata sebesar $91,88 \mathrm{kw} / \mathrm{ha}$.

2. Usahatani kacang panjang di Kecamatan Ambulu Kabupaten Jember menguntungkan. Keuntungan per hektar yang diperoleh petani yaitu sebesar Rp 7.702.100 dalam sekali produksi (3-3,5 bulan).

3. Hasil R/C pada usahatani kacang panjang per ha diperoleh 1,416 sehingga usahatani kacang panjang sudah efisien dalam penggunaan biaya produksi. 
4. Faktor-faktor produksi yang menunjukan pengaruh signifikan pada usahatani kacang panjang di Kecamatan Ambulu Kabupaten Jember terdiri dari luas lahan, jumlah pupuk dan jumlah tenaga kerja. Sementara faktor jumlah benih, dan jumlah pestisida tidak mempunyai pengaruh yang signifikan terhadap produksi usahatani kacang panjang di Kecamatan Ambulu Kabupaten Jember.

\section{Saran}

Berdasarkan permasalahan, pembahasan dan kesimpulan yang ada maka dapat dikemukakan saran sebagai berikut:

1. Bagi petani penggunaan luas lahan, jumlah pupuk, dan jumlah tenaga kerja ditambah dalam jumlah tertentu agar dapat meningkatkan jumlah produksi, namun secara teknis masih tetap berlangsung secara efisien dan secara ekonomis akan semakin menguntungkan.

2. Bagi peneliti yang akan melakukan penelitian pada komoditas yang sama diharapkan untuk mengkaji pada aspek pemasaran karena harga jual ditingkat petani jauh lebih rendah dibandingkan dengan harga tingkat pengecer.

3. Pemerintah hendaknya memberikan kebijakan untuk lembaga pemasaran dan petani terutama dalam harga, sehingga diharapkan bisa memberikan harga pasar yang layak guna meningkatkan keuntungan yang diperoleh petani.

\section{DAFTAR PUSTAKA}

Cahyono, B. 2005. Kacang Panjang Teknik Budidaya dan Analisis Usahataninya. Semarang.CV Aneka Ilmu.

Nizar, Usmanul. 2002. Analisis Faktor Produksi Yang Berpengaruh Terhadap Usahatani Kacang Panjang di Desa Andongsari Kecamatan Ambulu Kabupaten Jember. Fakultas Ekonomi Universitas Jember.

Reffi, Marura Dalti. 2014. Analisis Usahatani Kacang Panjang (Vignasinesis L) di Kecamatan Batang Kapas Kabupaten Pesisir Selatan. Fakultas Pertanian. Universitas Andalas

Saepul, Dede. 2013. Analisis Faktor-Faktor yang Mempengaruhi Produksi dan Pendapatan Usahatani Kacang Panjang di Kecamatan Nagrak Kabupaten Sukabumi. Departemen Agribisnis Fakultas Ekonomi dan Manajemen Institut Pertanian Bogor. Bogor.

Soekartawi. 1995. Analisis Usahatani. Jakarta : UI Press.

Soetriono. 2006. Pengantar Ilmu Pertanian. Jember.Bayu Media. 